\title{
Storage polysaccharides in germinating yellow lupine (Lupinus luteus L.)
}

\author{
ALEKSANDRA HOFFMANNOWA, GRAŻYA ZIELINSKA
}

Department of Plant Physiology, Institute of Biology, A. Mickiewicz University, Stalingradzka 14, 61-713 Poznań, Poland

(Accepted after revision on October 13, 1980)

\begin{abstract}
The yellow lupine (Lupinus luteus L. cv. Express) was cultured for 16 days in light or in darkness. During the first 3 days of germination starch and hemicelluloses were estimated in the seed organs, cotyledons and axis. Later the estimations were performed daily in cotyledons, shoots and roots of the cultured seedlings. Absence of starch was noted in cotyledons of air-dry seeds and an abrupt starch synthesis in the first 24 hours of germination. Degradation of starch, and hemicelluloses in cotyledons of the germinating yellow lupine was rapid and correlated strictly with losses in their dry weight. Similarly to starch synthesis, it showed no light dependence. On the other hand, light influenced synthesis of the studied polysaccharides in the shoot and the root of a developing lupine seedling.
\end{abstract}

\section{INTRODUCTION}

Our knowledge on the size of the pool and mobilization rate of storage materials in the endosperm or cotyledons is far from being complete. Data on the reactions linked to starch degradation during germination originate mainly from studies on cereals (D u r e 1960, F r y d e nberg and $\mathrm{Ni}$ i ls e n 1965, M u rat a et al. 1968, T a n a k a et al. 1970). Information on starch catabolism in Leguminosae are sparse and restricted almost exclusively to studies performed on the pea $(\mathrm{J} \mathrm{uli}$ a n o and V a rner 1969, Swain and Dekker 1966a, 1966b, 1969) and the lentil (Tárrago and Nicolás 1976).

Apart from starch, present in e.g. the pea and the bean, hemicelluloses constituting a component of cell walls are also storage polysaccharides. Hemicelluloses are present in the endosperm of e.g. Trigonella foenum-gracum (R e id 1971) or in the cotyledons (in pea, bean and lu- 
pine). Thus, the majority of Leguminosae form two polysaccharide-storing systems: starch grains within the cytoplasm and hemicelluloses in the cell walls. A similar role of hemicelluloses has also been observed in some monocotyledons ( $\mathrm{M}$ e i e r 1958, $\mathrm{M}$ a c L e o d and $\mathrm{S}$ a n d i e 1961).

Mobilization of hemicelluloses in the pea has been described by $\mathrm{Fl}$ i n $\mathrm{n}$ (1969) and in the bean - by $\mathrm{S} \mathrm{m}$ it h (1974). In air-dry yellow lupine seeds no starch could be detected in the cotyledons, whereas the walls are thick and become thin during germination (M $ł$ od zi a n ow$\mathrm{ski}$ and Wes ołow ska 1975). Examination of changes in the content of the studied polysaccharides during germination may be interesting also because starch is synthesized from sugars originating probably from hemicellulose degradation.

\section{MATERIAL AND METHODS}

Yellow lupine seeds (Lupinus luteus L. cv. Express) originating from the Plant Breeding Station in Gostyń Wielkopolski served as experimental material. The seeds were divided into weight classes (differing by $20 \mathrm{mg}$ ) and the most frequent class comprising seeds weighing 141 to $160 \mathrm{mg}$ was chosen for experiments.

The air-dry seeds were freed of seed coats and immersed in sterile distilled water for 3 hours. Then they were transferred to sterile Petri dishes lined with wet filter paper. Ten seeds were placed into each dish. The dishes were placed in controlled temperature chambers (a dark or an illuminated one $-1600 \mathrm{lux}$ ), at $24^{\circ} \mathrm{C}$. After 24 hours the seeds were transferred to fresh Petri dishes and 48 hours after immersion the germinating seeds were transferred to hydroponic culture containers filled with sterile distilled water. The containers were placed in dark or illuminated controlled temperature chambers. The culture was maintained for 16 days with daily renewal of water in the containers.

Each day a sample of 30 seedlings was taken and for the first three days of culture the seedlings were divided into cotyledons and axes. Starting on day 4, the seedlings were divided into cotyledons, shoots and roots. Dry weight of the organs was estimated. For estimation of starch and hemicelluloses freeze-dried material was used. Four culture series were conducted and all estimations were performed four times in each series. Dry weight, starch content and hemicelluloses content were computed per organ (for shoots and roots) or per pair of cotyledons.

Estimation of starch and hemicellulose content. Freeze-dried material (40 mg) was triple extracted with $5 \mathrm{ml} 70 \%$ ethanol at 60 to $70^{\circ} \mathrm{C}$ to remove soluble sugars. Starch content was estimated as described earlier (H offmannow a 1978). Hemicellulose content was estimated in the sediment obtained following enzymatic starch hydrolysis. The sediment 
was suspended in $5 \mathrm{ml}$ distilled water and placed in a boiling water bath for 4 hours. Every hour the sample was centrifuged, the supernatant was decanted and the sediment resuspended in destilled water. Such depectination was proven to be sufficient since no uronic acid could be subsequently detected in the sample by the reaction with orcinol. Following removal of pectins, the sediment was washed twice in warm distilled water and spun down. It was suspended again in $4 \mathrm{ml} \mathrm{H}_{2} \mathrm{O}, 0.7 \mathrm{ml} 20 \%$ $\mathrm{HCl}$ was added and the sample underwent hydrolysis for 3 hours in a boiling water bath. The sample was neutralized with $1.5 \mathrm{ml}$ saturated $\mathrm{Na}_{2} \mathrm{CO}_{3}$ solution and deproteinized with $0.6 \mathrm{ml} 10 \%$ sodium tungstate

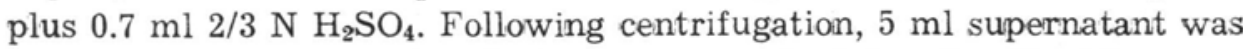
taken for estimation of reducing sugar content by the $\mathrm{H}$ off $\mathrm{mann}$ (1938) micromethod, performed as in starch estimation (colorimetric reading at $420 \mathrm{~nm}$ ). Hemicellulose content was calculated with the use of coefficient 0.9 .

\section{RESULTS}

As evident from the data in Table 1 in air-dry seeds starch was present only in the embryonic axis in a small amount while it was totally absent from the cotyledons. Hemicellulose content was low in the embryonic axis while it was relatively high in the cotyledons.

Table 1

Dry weight, starch content and hemicelluloses content in cotyledons and embryonic axis of air-dry seeds of yellow lupine (Lupinus luteus

L. cv. Express)

\begin{tabular}{|l|c|c|}
\hline & $\begin{array}{c}\text { Mg per } \\
\text { embryonic axis }\end{array}$ & $\begin{array}{c}\text { Mg per pair of } \\
\text { cotyledons }\end{array}$ \\
\hline Dry weight & 2.8 & 110.0 \\
Starch & 0.017 & 0 \\
Hemicelluloses & 0.013 & 1.50 \\
\hline
\end{tabular}

CULTURE IN LIGHT

Dry weight

Cotyledons of lupinus seedlings showed a decline of dry weight in the first days of culture. Later there were little or no changes in their dry weight (Fig. 1A). In the axis (Table 2) and in the shoot (Fig. 2A) an apparent increase of dry weight was visible mainly in the first period of culture. From the seventh day dry weight augmented slowly. There was a very slow dry weight increase in the lupine seedling rooit throughout the culture period (Fig. 2B). 
Table 2

Dry weight, starch content and hemicellulose contert in the intact axis (mg per axis). For the first 3 days of culture the axis was not divided into shoot and root

\begin{tabular}{|c|c|c|c|c|c|c|}
\hline \multirow{2}{*}{$\begin{array}{c}\text { Day } \\
\text { of culture }\end{array}$} & \multicolumn{2}{|c|}{ Dry weight } & \multicolumn{2}{|c|}{ Starch } & \multicolumn{2}{|c|}{ Hemicelluloses } \\
\hline & light & darkness & light & darkness & light & darkness \\
\hline 1 & 8.9 & 4.8 & 0.166 & 0.087 & 0.039 & 0.039 \\
\hline 2 & 10.4 & 11.2 & 0.266 & 0.285 & 0.069 & 0.067 \\
\hline 3 & 15.0 & 14.0 & 0.395 & 0.167 & 0.066 & 0.065 \\
\hline
\end{tabular}

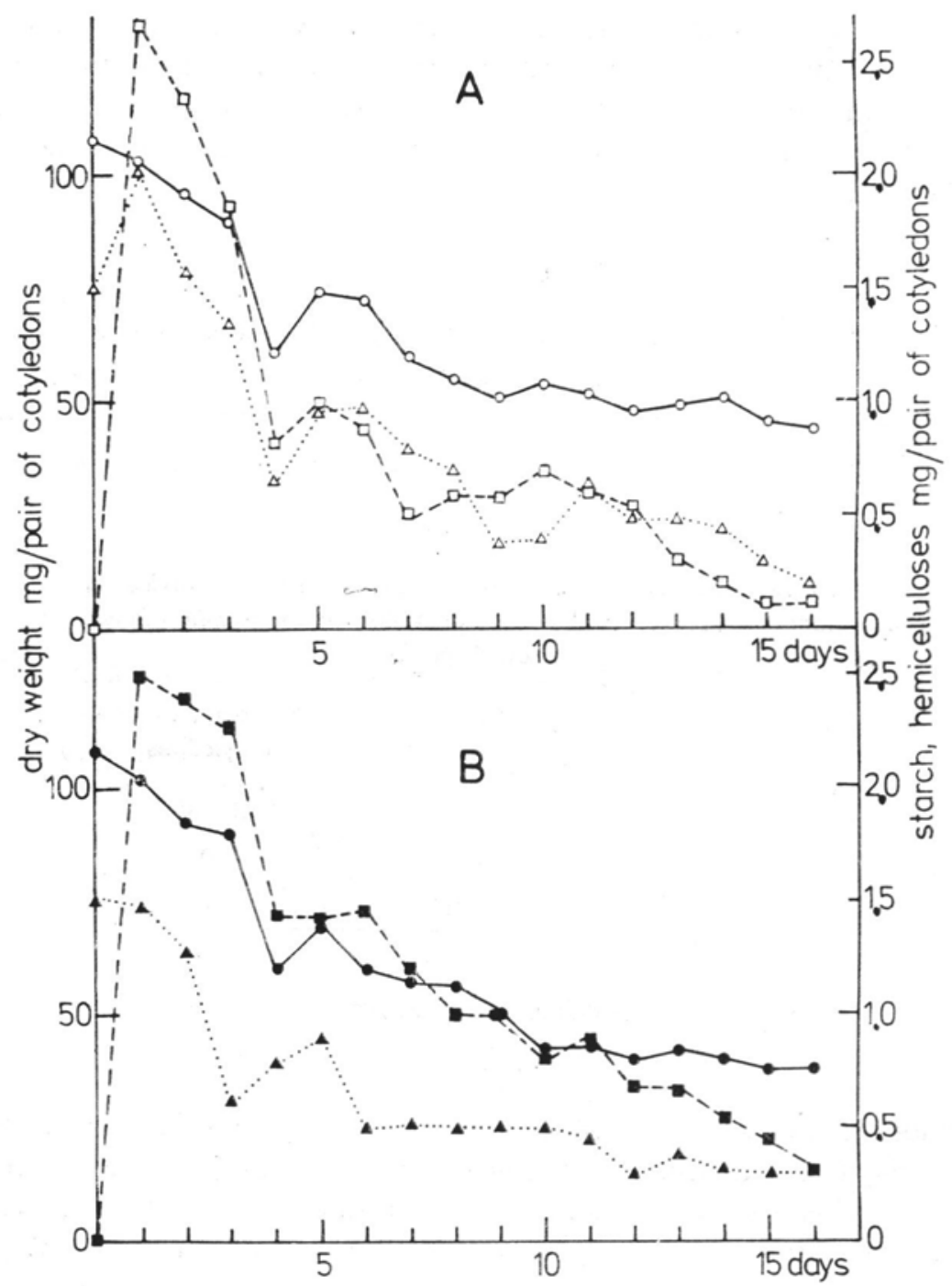

Fig. 1. Dry weight, starch and hemicelluloses in cotyledons of yellow lupine seedlings cultured under light (A) and in darkness (B)

Circles - dry weight, squares - starch, triangles - hemicelluloses 


\section{Starch}

Cotyledons of lupine seedlings contained maximum starch amounts in the first day of culture (Fig. 1A). The peak was followed by a decrease parallel to dry weight losses and most intense in the first days of culture. In the last days starch content in the cotyledons was close to none.

In the seedling axis starch content augmented rapidly during the first 3 days (Table 2), and in the shoot the sixth day (Fig. 2A). Later

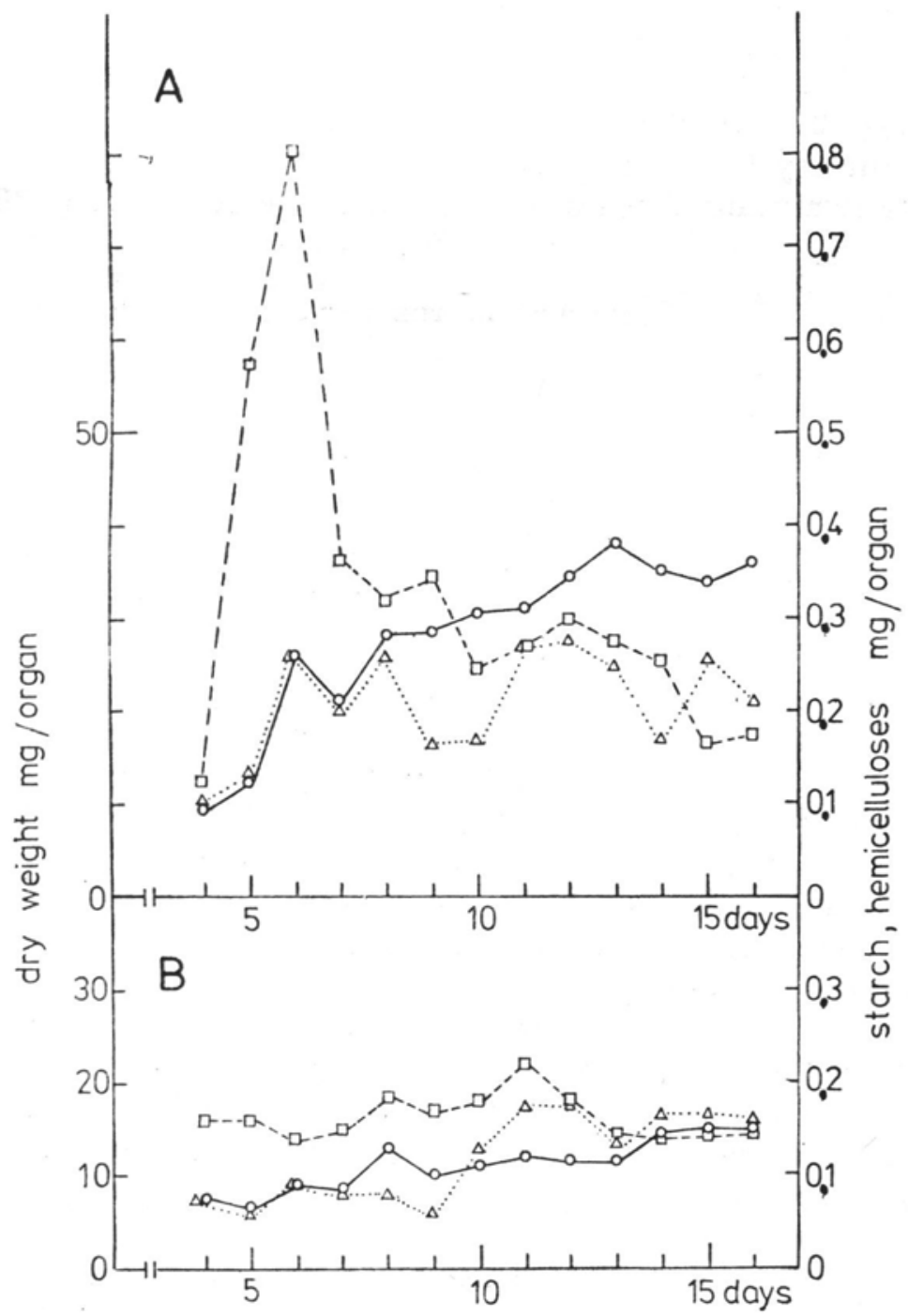

Fig. 2. Dry weight, starch and hemicelluloses in organs of yellow lupine seedlings cultured under light

A - shoot, B - root. For other details see Fig. 1 
the amount of starch diminished sharply for one day and then the decrease was slower till the end of the culture. In the root, starch content remained at an almost constant level throughout the culture period (Fig. 2B).

\section{Hemicelluloses}

The decrease in hemicellulose level in the cotyledons parallelled the decrease in dry weight. The decrease in hemicellulose content was particularly rapid in the first few days of culture (Fig. 1A). Changes in hemicellulose content in the seedling axis were relatively small (Table 2). Similarly, an increase in hemicellulose content in the shoot was not: abrupt (Fig. 2A). In the root a constant level of hemicelluloses was observed till day 9 , followed by an increase for two days. There were no further significant changes till the end of the culture (Fig. 2B).

\section{CULTURE IN THE DARK}

\section{Dry weight}

Dry weight losses in the cotyledons of lupine seedlings were similar to those under light (Fig. 1B). At the end of the culture period dry weight was lower than under light. The dry weight gains in the shoot and the root seemed higher than in seedlings cultured in light (Fig. 3A and $\mathrm{B})$.

\section{Starch}

Similarly to the cultures in light, seedling cotyledons contained maximum starch amounts in the first day of culture. The decrease in starch content strictly parallelled dry weight losses and was most intense at the beginning of culture (Fig. 1B). At the end of culture the cotyledons contained more starch than those grown in light.

In the seedling axis starch content increased for the first two days of culture to decrease on the third day (Table 2). However, the starch level in the shoot augmented in the first days of culture to decrease on the ninth day, and rise again and decrease towards the end of culture, as evident from Fig. 3A. In the root the estimates indicated an increase in starch content followed by a decrease.

\section{Hemicelluloses}

Similarly to the cultures in light, the decrease of hemicelluloses content in cotyledons of lupine seedlings correlated strictly with dry weight losses. It was most rapid in the first days of culture (Fig. 1B). At the 


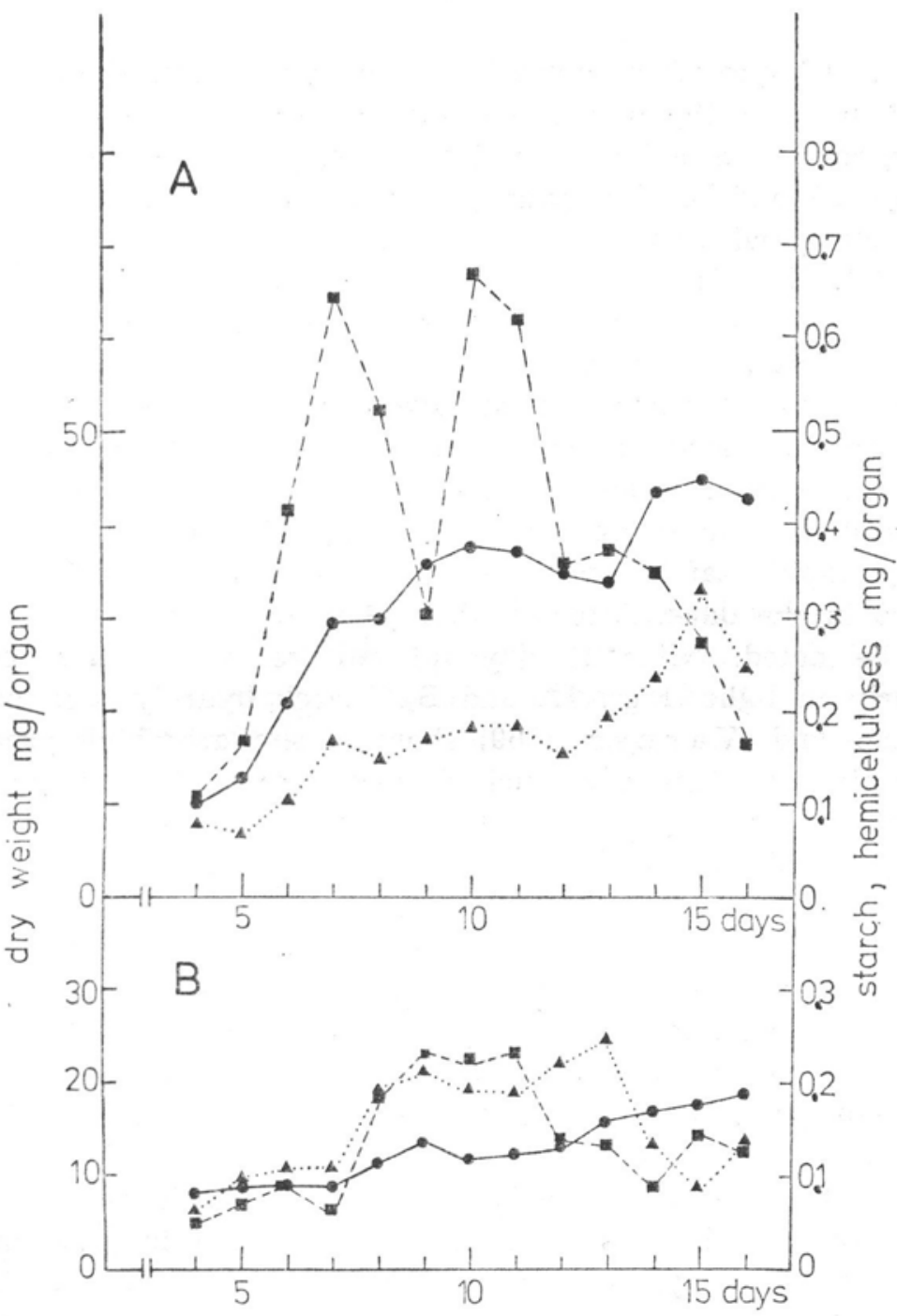

Fig. 3. Dry weight, starch and hemicelluloses in organs of yellow Iupine seedlings cultured in darkness A - shoot, B - root. For other details see Fig. 1

end of culture the cotyledons contained somewhat more hemicelluloses than those cultured in light.

Hemicellulose content in the seedling axis equalled that seen in cultures grown in light (Table 2). In the shoot, hemicellulose content increased, paralleling the increase in dry weight (Fig. 3A). On the other hand, in the root no correlation with dry weight could be noted, despite perceptible changes in hemicellulose content (Fig. 3B). 


\section{DISCUSSION}

Within 24 hours after immersion of the seeds hemicellulose hydrolysis commences in the cotyledons and progresses rapidly in the first days of germination. After a few days hydrolysis slows down, as evident from Figs. 1A and B. The hydrolysis yields simple sugars, mainly glucose, galactose and xylose (M e yer and $\mathrm{P}$ ol jak off-M a ber 1963 . Reid 1971, Hoffmannowa and Domka 1977). Hemicellulose synthesis in the shoot and root is linked with the formation of new cell walls. It is slow (Figs. 2 and 3).

Hemicelluloses constitute a storage polysaccharide in lupine cotyledons. Their degradation products may serve as substrates for starch synthesis. The peak levels of starch synthesis are seen in cotyledons 24 hours after immersing the seeds (Figs. 1A and B). This extraordinarily rapid starch synthesis is light-independent since it takes place also in the dark. After another 24 hours starch degradation can already be noted. After 16 days of culture it is almost complete, particularly in light (Figs. 1A and B). Starch hydrolysis in pea seeds (Juliano and Varner 1969) shows a similarly high pace, while in the lentil cotyledons it is much slower: after 13 days of germination approximately $50 \%$ of the original starch cantent can still be detected (Tárrago and N i colás 1976).

It is difficult to find out whether in the second and subsequent days of germination starch synthesis still takes place in the cotyledons of the yellow lupine. Possibly, the synthesis is restricted only to the first 24 hours and, later, only hydrolysis takes place. Possibly alsu the synthesis continues, but is masked by parallel degradation.

Hemicellulose mobilization in cotyledons is intense (Figs. 1A and B) and it can hardly be assumed that hemicellulose degradation products supply starch synthesis for only one day. At the same time in the seedling axis, and in particular in the shoot, the increase in starch level in the first days of germination is quite significant (Table 2, Figs. 2 and 3).

Most intriguing is, however, the abrupt starch synthesis changing in one day the starch level in the cotyledons from nil (Table 1, Figs. 1A and B) to top values. Possibly, the maximum starch level was present earlier than after 24 hours from the start of the culture. No earlier estimations have, however, been performed. Młodzianowski and Wes ołowska (1975) as well as Czosnowski et al. (1978) have detected the appearance of starch grains at earliest after $24 \mathrm{hrs}$ of lupine germination.

It is of interest to compare the kinetics of mobilization of the two storage polysaccharides in cotyledons to the kinetics of their synthesis in the shoot and root. Degradation in the cotyledons is rapid and is 
characterized by a linear correlation with decreasing dry weight. It follows that translocation of hydrolysis products to the axis is also intense: only a small proportion of them is utilized to support cotyledon respiration (Guardiola and $\mathrm{Sutcliffe} \mathrm{1972).} \mathrm{On} \mathrm{the} \mathrm{other} \mathrm{hand,}$ synthesis of hemicelluloses and starch in the axis is much slower (Figs. 2 and 3). The synthesis differs (in its rate its correlation with increasing dry weight) in the root and in the shoot, pointing to a metabolic specificity of the organs.

The results obtained in illuminated cultures and in those kept in darkness prove that light hardly affects to any greater extent the mobilization of polysaccharides, particularly starch. On the other hand, light markedly affects synthesis of starch and hemicelluloses in the shoot and root of lupine seedlings. The same applies to the content of the studied polysaccharides and to the kinetics of their synthesis. It is not known whether light affects only the translocation rate from cotyledons (Guardiola and Sutcliffe 1972) or directly affects the rate of synthesis. Individual organs, cotyledons and the axis in particular, differ markedly in their reaction to light. It is still more interesting if one considers that lupine cotyledons are epigeic and become green soon after emergence.

Hence, the effect of light on degradation and synthesis processes during germination seems to require further studies. Quantitative estimations of simple sugars may be important in supplementing these studies.

\section{REFERENCES}

Czosnowski E., Lorenc-Plucińska G., Jańczak-Dopierała E., 1978. Distribution and mobilization of reserve substances and localization of spherosomes in the cotyledons of Lupinus luteus L. Bull. Soc. Amis Sci. Lettr. Poznań, Ser. D. 18: 3-13.

Dure L. S., 1960. Site of origin and extent of activity of amylases in maize endosperm. Plant Physiol. 35: 925-934.

Flinn A. M., 1969. A nutritional study of fruit maturation in Pisum arvense L. Ph. D. Thesis., The Queen's University Belfast.

Frydenberg O., $\mathrm{N}$ ielsen G., 1965. Amylase izoenzymes in germinating barley seeds. Hereditas 54: 123-139.

Guardiola J. L., Sutcliffe J. F., 1972. Transport of materials from the cotyledons during germination of seeds of the garden pea (Pisum sativum L.). J. Exp. Bot. 23: 322-337.

$\mathrm{H}$ offmann W. S., 1938. A rapid photometric method for the determination of glucose in blood and urine. J. Biol. Chem. 120: 51-55.

Hoffmannowa A., 1978. Cantrol of starch mobilization in cotyledons of germinating yellow lupine (Lupinus luteus L.). Bioch. Physiol. Pflanzen 173: 181-185.

Hoffmannowa A., Domka L., 1977. Soluble sugars in seedling organs and isolated cotyledons of Lupinus luteus L. Bull. Soc. Amis Sci. Lettr. Poznań, ser. D., 17: 79-84. 
Juliano B. O., Varner J. E., 1969. Enzymic degradation of starch granules in the cotyledons of germinating peas. Plant Physiol. 44: 866-892.

M a c Le od A. M., Sandie R., 1961. Cell wall metabolism. I. Hemicelluloses of Bromus seeds. New Phytol. 60: 117-128.

Meier H., 1958. On the structure of cell walls and cell wall mannans from ivory nuts and from dates. Bioch. Biophys. Acta 28: 229-240.

Meyer A. M., Poljak off-Mayber A., 1963. The germination of seeds. London, Pergamon Press.

M lodzian ow ski F., Wes ołowska A., 1975. Morphological aspects of starch and cell wall material mobilization in developing lupine cotyledons and the effect of kinetin on these processes. Acta Soc. Bot. Pol. 44: 529-536.

Murata T., Akazawa T., Furuchi S., 1968. Enzymic mechanism of starch breakdown in germinating rice seeds. I. An analytical study. Plant Physiol. 43: 1899-2005.

Reid J. S. G., 1971. Reserve carbohydrate metabolism in germinating seeds of Trigonella foenum-graecum L. (Leguminosae). Planta (Berl.) 100: 131-142.

Smith D. L., 1974. A histological and histochemical study of the cotyledons of Phaseolus vulgaris L. during germination. Protoplasma 79: 41-57.

Swa in R. R., Dekker E. E., 1966a. Seed germination studies I. Purification and properties of an $\boldsymbol{\alpha}$-amylase from the cotyledons of germinating peas. Bioch. Biophys. Acta 122: 75-86.

Swain R. R., Dekker E. E., 1966b. Seed germination studies. II. Pathways for starch degradation in germinating pea seedlings. Bioch. Biophys. Acta 122: $87-100$.

Swa in R. R., Dekker E. E., 1969. Seed germination studies. III. Properties of a cell-free amino acid incorporating system from pea cotyledon; possible origin of cotyledonary $\boldsymbol{\alpha}$-amylase. Plant Physiol. 44: 319-325.

Tanaka Y., Ito T., Akazawa T., 1970. Enzymic mechanism of starch breakdown in germinating rice seeds. III. $\alpha$-amylase izoenzymes. Plant Physiol. 46: 650-654.

Tárrago J. F., Nicolás G., 1976. Starch degradation in the cotyledons of germinating lentils. Plant Physiol. 58: 618-621.

\section{Polisacharydy zapasowe $w$ kietkujacym łubinie żółtym}

\section{Streszczenie}

Łubin żółty hodowano przez 16 dni od wysiania, na świetle i w ciemności. W organach nasienia, liścieniach i osi, oznaczano zawartość skrobi i hemiceluloz przez pierwsze 3 dni kiełkowania. W dalszym okresie hodowli oznaczenia te wykonywano codziennie w liścieniach, pędach i korzeniach. Stwierdzono brak skrobi w liścieniach powietrznie suchych nasion oraz jej gwałtowną syntezę w pierwszych 24 godzinach kiełkowania. Degradacja skrobi i hemiceluloz w liścieniach kiełkującego łubinu jest szybka, ściśle skorelowana $z$ ubytkiem suchej masy. Degradacja ta jest niezależna od światła podobnie jak synteza skrobi. Swiatło natomiast wywiera wpiyw na syntezę badanych polisacharydów w pędzie i korzeniu rozwijającej się siewki łubinu żółtego. 